\title{
Human $\beta_{3}$-Adrenoreceptor is Resistant to Agonist-Induced Desensitization in Renal Epithelial Cells
}

\author{
Serena Milano Andrea Gerbino $^{\mathrm{a}}$ Giorgia Schena $^{\mathrm{b}} \quad$ Monica Carmosino $^{\mathrm{b}}$ \\ Maria Svelto ${ }^{\mathrm{a}}$ Giuseppe Procino ${ }^{\mathrm{a}}$ \\ aDepartment of Biosciences, Biotechnologies and Biopharmaceutics, University of Bari, Bari, \\ bDepartment of Sciences, University of Basilicata, Potenza, Italy
}

\section{Key Words}

$\beta_{3}$-adrenoreceptor $•$ Mirabegron $\cdot \mathrm{CAMP}$ and $\mathrm{Ca}^{2+}$ signaling $\bullet$ Desensitization $\cdot$ Internalization - Downregulation - Type-2 vasopressin receptor - Aquaporin 2 - Nephrogenic diabetes insipidus

\begin{abstract}
Background/Aims: We recently showed that the $\beta_{3}$-adrenoreceptor $\left(\beta_{3} A R\right)$ is expressed in mouse kidney collecting ducts (CD) cells along with the type-2 vasopressin receptor (AVPR2). Interestingly, a single injection of a $\beta_{3} A R$ selective agonist promotes a potent antidiuretic effect in mice. Before considering the feasibility of chronic $\beta_{3} A R$ agonism to induce antidiuresis in vivo, we aimed to evaluate in vitro the signaling and desensitization profiles of human $\beta_{3} A R$. Methods: Human $\beta_{3} A R$ desensitization was compared with that of human AVPR2 in cultured renal cells. Video imaging and FRET experiments were performed to dissect $\beta_{3} A R$ signaling under acute and chronic stimulation. Plasma membrane localization of $\beta_{3} A R, A V P R 2$ and AQP2 after agonist stimulation was studied by confocal microscopy. Receptors degradation was evaluated by Western blotting. Results: In renal cells acute stimulation with the selective $\beta_{3} A R$ agonist mirabegron, induced a dose-dependent increase in cAMP. Interestingly, chronic exposure to mirabegron promoted a significant increase of intracellular cAMP up to 12 hours. In addition, a slow and slight agonist-induced internalization and a delayed downregulation of $\beta_{3} A R$ was observed under chronic stimulation. Furthermore, chronic exposure to mirabegron promoted apical expression of AQP2 also up to 12 hours. Conversely, long-term stimulation of AVPR2 with dDAVP showed short-lasting receptor signaling, rapid internalization and downregulation and apical AQP2 expression for no longer than $3 \mathrm{~h}$. Conclusions: Overall, we conclude that $\beta_{3} A R$ is less prone than AVPR2 to agonist-induced desensitization in renal collecting duct epithelial cells, showing sustained CAMP production, preserved membrane localization and delayed degradation after 12 hours agonist exposure. These results may be important for the potential use of chronic pharmacological stimulation of $\beta_{3} A R$ to promote antidiuresis overcoming in vivo renal concentrating defects caused by inactivating mutations of the AVPR2.

S. Milano and A. Gerbino contributed equally to this work.

\begin{tabular}{ll}
\hline Prof. Giuseppe Procino, & Department of Biosciences, Biotechnologies and Biopharmaceutics, University of Bari \\
Assistant Professor of & Bari (Italy) \\
Physiology & Tel. +39-080-5443414, E-Mail giuseppe.procino@uniba.it
\end{tabular}
\end{abstract}




\section{Cellular Physiology Cell Physiol Biochem 2018;48:847-862 \begin{tabular}{l|l} 
DOI: 10.1159/000491916 & $\begin{array}{l}\text { O } 2018 \text { The Author(s). Published by S. Karger AG, Basel } \\
\text { www.karger.com/cpb }\end{array}$
\end{tabular} \\ Milano et al.: $\mathrm{B}_{3}$ ar Desensitization in Renal Cells}

\section{Introduction}

$\beta_{3}$-adrenoreceptor $\left(\beta_{3} \mathrm{AR}\right)$ is a G-protein coupled receptor (GPCR) discovered and cloned in the 1980s [1-3]. Early studies demonstrated that human $\beta_{3} A R$ is expressed primarily in both white and brown adipocytes where regulates lipolysis and thermogenesis [2]. More recent reports indicate that $\beta_{3} \mathrm{AR}$ is also expressed in human heart, gallbladder, gastrointestinal tract, prostate and urinary bladder detrusor, brain as well as in near-term myometrium [4].

We recently showed, for the first time that, the $\beta_{3} \mathrm{AR}$ is also expressed in different nephron segments of mouse kidney. In the cortical and outer medullary collecting duct, $\beta_{3} \mathrm{AR}$ shares its localization with the vasopressin type-2 receptor (AVPR2), whose activation by vasopressin (AVP) is critical for the shuttling of the water channel aquaporin 2 (AQP2) at the apical plasma membrane, increase of water reabsorption and, ultimately, antidiuresis. We proved, in fact, that short-term $\beta_{3} A R$ selective agonism promoted a potent antidiuretic effect in mice lacking AVPR2 [5].

These results are relevant when considering $\beta_{3} A R$ as a potential drug target for the treatment of X-linked Nephrogenic Diabetes Insipidus (X-NDI) [6-9], a congenital disease caused by inactivating mutations of the AVPR2 and consequential lack of AVP-induced antidiuresis.

To consider a possible chronic use of $\beta_{3} \mathrm{AR}$ agonists as therapeutic approach for X-NDI it is mandatory to evaluate whether and when the receptor undergoes desensitization switching off its downstream signaling with reduction of agonist response and clinical efficacy of the drug. In general, desensitization of a GPCR results in decreased responsiveness to repeated or chronic exposure to agonist. Desensitization mechanisms include: 1) receptor uncoupling from downstream signal transduction elements mediated by kinases; 2 ) receptor internalization; 3) receptor down-regulation via increased degradation and/or reduced synthesis [10-12].

It is well established that agonist-promoted desensitization of both $\beta_{1}$ - and $\beta_{2}$ adrenoreceptors is mainly due to phosphorylation of the receptors by several kinases including the $\beta$ adrenoreceptor kinase ( $\beta A R K)$ and the cAMP-dependent protein kinase $A$ (PKA) [13-15]. $\beta_{3} A R$, unlike $\beta_{1}$ - and $\beta_{2}$-AR, lacks the target amino acid sequences for $\beta A R K$ and PKA in the cytoplasmic $\mathrm{C}$-terminus.

Consequently, $\beta_{3}$ AR should be less susceptible to PKA/ $\beta$ ARK-mediated receptor recycling and desensitization in response to hyperstimulation [16-18].

Still, the question whether the $\beta_{3} \mathrm{AR}$ is subject to desensitization is a matter of debate. On one hand, it has been shown that $\beta_{3} \mathrm{AR}$ transfected into Chinese hamster ovary (CHO) cells $[14,19,20]$, murine L fibroblast cells and chinese hamster fibroblast (CHW) cells [18, 21] or endogenously expressed in human SK-N-MC neuroblastoma cells [16] was resistant to both short- and long-term agonist-induced desensitization. Experiments to investigate desensitization in rodent adipose tissue did not shed a light on this controversial picture $[13,22-25]$. On the other hand, agonist-induced $\beta_{3} A R$ desensitization was demonstrated in mouse ileum [24] and with human embryonic kidney (HEK) cells transfected with $\beta_{3}$ AR [14, 26].

Overall, these findings suggest that agonist-induced desensitization of $\beta_{3}$-adrenoceptors occurs in a tissue- or cell type-dependent manner [27].

Therefore, the present study was designed to specifically explore human $\beta_{3} A R$ desensitization dynamics in renal collecting duct epithelial cells, which have not been described so far. The evaluation of long-term desensitization could be important for unveiling the potential tachyphylaxis occurring during chronic treatment of X-NDI with $\beta_{3}$ AR agonists. In this respect, we analyzed signal transduction pathways, membrane trafficking and expression level of $\beta_{3} A R$ chronically stimulated with the specific agonist mirabegron which has been already introduced into the clinic for treatment of overactive bladder syndrome $[28,29]$. 


\section{Cellular Physiology Cell Physiol Biochem 2018;48:847-862 \begin{tabular}{l|l} 
and Biochemistry Published online: July 20, 2018 & $\begin{array}{l}\text { C } 2018 \text { The Author(s). Published by S. Karger AG, Basel } \\
\text { www.karger.com/cpb }\end{array}$
\end{tabular} Milano et al.: $\mathrm{B}_{3}$ ar Desensitization in Renal Cells}

To this end, we stably expressed the $\beta_{3} \mathrm{AR}$ tagged with mCherry in mouse collecting duct M-1 cells [30] and compared these results with data from M-1 cells expressing human AVPR2, whose desensitization dynamics were well characterized in the collecting duct [3134].

Here, we found that $\beta_{3} \mathrm{AR}$ is less prone than AVPR2 to agonist-induced desensitization in renal collecting duct epithelial cells, showing sustained cAMP production, persistent membrane localization and delayed degradation under long-term agonist exposure. Of note, the sustained cAMP signaling induced by $\beta_{3} A R$ activation deeply impact AQP2 membrane localization, which is continuously expressed on the apical membrane for up to $12 \mathrm{~h}$.

These results encourage preclinical studies supporting the hypothesis that chronic mirabegron treatment could promote a durable antidiuretic effect in X-NDI patients.

\section{Materials and Methods}

\section{Antibodies and Reagents}

1-deamino-8-D-arginine vasopressin (dDAVP, cat.\# V-1005) and cycloheximide (cat.\# c1988) were from Sigma (www.sigmaaldrich.com), while mirabegron (cat.\# sc211912) was from Santa Cruz Biotechnology (www.scbt.com). Mouse monoclonal anti- $\mathrm{Na}^{+} / \mathrm{K}^{+}$-ATPase $\alpha-1$ antibody (cat.\# 05-369) was from Millipore (www.merckmillipore.com), rabbit anti-mCherry (cat.\# ab167453) from Abcam (www.abcam.com) and polyclonal anti-FLAG® (cat.\# F7425) from Sigma. The rabbit affinity-purified polyclonal antibody against human AQP2 was previously described [35].

\section{cDNA constructs of $\beta_{3} A R-m C h / F L A G ~ \circledR ~ a n d ~ A V P R 2-m C h$}

Human $\beta_{3}$-adrenoreceptor $\left(\beta_{3} A R\right)$, cloned in pcDNA3.1 plasmid, and human vasopressin type 2 receptor (AVPR2), cloned in pRP vector, were from ThermoFisher (www.thermofisher.com) and Cyagen (www.cyagen.com), respectively. The fluorescent tag mCherry was attached to the carboxy-terminus of both receptors. The human $\beta_{3} A R$ cloned in pRP vector tagged with FLAG® at C-terminus was from Cyagen.

\section{Cell culture and transfection}

Mouse cortical collecting duct M-1 cells [30] and MCD4 cells, a clone of M-1 cells stably transfected with human- AQP2, were cultured as described elsewhere [36, 37]. To obtain stable cell lines expressing $\beta_{3} \mathrm{AR}-$ $\mathrm{mCh}\left(\mathrm{M}-1-\beta_{3} \mathrm{AR}-\mathrm{mCh}\right.$ and MCD4- $\left.\beta_{3} \mathrm{AR}-\mathrm{mCh}\right)$ or AVPR2-mCh (M-1-AVPR2-mCh and MCD4-AVPR2-mCh) cells were transfected using Lipofectamine ${ }^{\circ} 2000$ (www.thermofisher.com) and the appropriate construct according to the manufacturer's instructions. After 14-20 days of selection in medium containing $500 \mu \mathrm{g} / \mathrm{ml}$ hygromicin B (www.thermofisher.com), resistant colonies were isolated with cloning rings and expanded to evaluate expression and membrane localization of $\beta_{3} \mathrm{AR}-\mathrm{mCh}$ or AVPR2-mCh. In parallel experiments M-1 cells were transiently transfected using Lipofectamine ${ }^{\circledR} 2000$ with $\beta_{3}$ AR-FLAG®.

\section{FRET-based measurement of cAMP/PKA in single cells}

The FRET-based cAMP sensor Epac H96 [38] was a generous gift of Prof. Kees Jalink (Netherlands Cancer Institute, Amsterdam, Netherlands). AKAR4 [39] was kindly provided by Prof. Jin Zhang (John Hopkins University School of Medicine, Baltimore, MD). Cells were seeded on $\varnothing 25 \mathrm{~mm}$ glass coverslips and transiently transfected with Epac H96 or AKAR4 using Lipofectamine® 2000 (www.thermofisher. com). Cells were mounted in a perfusion chamber (FCS2 Closed Chamber System, www.bioptechs.com) and imaged using 40× Plan Fluor (NA 1.30) oil immersion objective lens. An Hepes-buffered Ringer's solution was used to perfuse cells during the experiment, containing: $140 \mathrm{mM} \mathrm{NaCl}, 5 \mathrm{mM} \mathrm{KCl}, 1 \mathrm{mM} \mathrm{MgCl}, 10 \mathrm{mM}$ Hepes, 5 mM Glucose, $1.0 \mathrm{mM} \mathrm{CaCl}_{2}$, pH 7.4.

Real-time FRET imaging experiments were performed at room temperature using a fluorescence ratio imaging system built around a TE2000-S inverted fluorescence microscope equipped with a cooled CCD camera (CoolSNAP HQ www.photometrics.com). MetaFluor software (www.moleculardevices.com) was used to acquire ratio data. FRET emission ratios (535 nm/485 nm, $440 \mathrm{~nm}$ excitation) were acquired every $5 \mathrm{~s}$. The fluorescence of mCherry (excitation $585 \mathrm{~nm}$, emission $610 \mathrm{~nm}$ ) did not interfere with any of these measurements [40]. Figures depict data from 5-8 cells summarized for each experiment; at least four independent runs were conducted. Data are expressed as means \pm SEM. 


\section{Cellular Physiology Cell Physiol Biochem 2018;48:847-862 \begin{tabular}{l|l|l} 
and Biochemistry 10.1159/000491916 & $\begin{array}{l}\text { D } 2018 \text { The Author(s). Published by S. Karger AG, Basel } \\
\text { www.karger.com/cpb }\end{array}$
\end{tabular} \\ Milano et al.: $\mathrm{B}_{3}$ ar Desensitization in Renal Cells}

Steady state FRET experiments were performed to measure intracellular cAMP levels in single cells using Epac H96 [38], as previously described [35, 41].

Briefly, M-1- $\beta_{3} \mathrm{AR}-\mathrm{mCh}$ and M-1-AVPR2-mCh cells were grown onto $\emptyset 25 \mathrm{~mm}$ glass coverslips at $37^{\circ} \mathrm{C}$ and transfected with Epac H96 using Lipofectamine ${ }^{\circledR}$ 2000. 12 hours before the experiment cells were treated overnight with $50 \mu \mathrm{M}$ indomethacin, a cyclooxygenase inhibitor, to prevent the increase in basal cAMP concentration due to autocrine/paracrine stimulation of P2-purinergic receptors [42, 43], as previously reported [36]. M-1- $\beta_{3} \mathrm{AR}-\mathrm{mCh}$ and M-1-AVPR2-mCh cells were either left under basal condition or stimulated for $1 \mathrm{~h}$ at $37^{\circ} \mathrm{C}$ with increasing doses of mirabegron or dDAVP: $1 \mathrm{nM}, 10 \mathrm{nM}, 100 \mathrm{nM}$ and $1 \mu \mathrm{M}$.

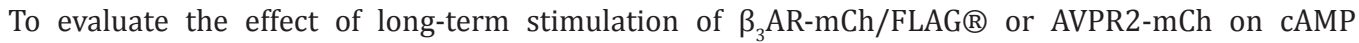
production, Epac H96-expressing cells were pretreated for $30 \mathrm{~min}$ with $10 \mu \mathrm{g} / \mathrm{ml}$ cycloheximide, a protein synthesis inhibitor, to prevent the potential contribution of newly synthesized receptor. Cells were either left under basal condition or treated with $10 \mathrm{nM}$ mirabegron or $100 \mathrm{nM}$ dDAVP for $1,3,6,12$ and $24 \mathrm{~h}$ at $37^{\circ} \mathrm{C}$ in presence of $10 \mu \mathrm{g} / \mathrm{ml}$ cycloheximide. After stimulation, cells were fixed in PBS containing $4 \%$ paraformaldehyde and mounted on glass slides.

Steady state FRET measurements were carried out using MetaMorph software (www.moleculardevices. com). Data from 15 different fields, each one containing at least 3 H96-expressing cells, were summarized for a single coverslip/treatment, and at least three independent coverslips were blind-analyzed. Averaged netFRET values from the different experimental conditions were normalized as percentage of the netFRET of unstimulated cells. netFRET data were analyzed using Prism software (version 5.0; www.graphpad.com). Unpaired data were assessed for statistical significance using the Student's t test. Data are expressed as means \pm SEM and $\mathrm{P}<0.05$ was considered statistically significant.

\section{Evaluation of cytosolic levels with Fura-2}

For intracellular $\mathrm{Ca}^{2+}$ measurements, M-1- $\beta_{3} \mathrm{AR}-\mathrm{mCh}$ or M-1-AVPR2-mCh cells were seeded on glass coverslips ( $\varnothing 25 \mathrm{~mm}$ ). Ringer's Solution was used to perfuse cells during the experiment containing 140 $\mathrm{mM} \mathrm{NaCl}, 5 \mathrm{mM} \mathrm{KCl}, 1 \mathrm{mM} \mathrm{MgCl}$, $10 \mathrm{mM}$ Hepes, $5 \mathrm{mM}$ Glucose, $1.0 \mathrm{mM} \mathrm{CaCl}{ }_{2}$ pH 7.4. Cells were loaded with $5 \mu \mathrm{M}$ Fura-2 (www.thermofisher.com) for $25 \mathrm{~min}$ at $37^{\circ} \mathrm{C}$ in DMEM. Coverslips with dye-loaded cells were analyzed with a set-up described in detail in previous papers of our group [41,44,45]. Fluorescence measurements were performed using Metafluor (www.moleculardevices.com). After background images correction, Fura-2 ratio was normalized to an average $2 \mathrm{~min}$. baseline (R0) before agonist addition to obtain the relative $\mathrm{R} / \mathrm{R}_{0}$. Figure depict 4 different cells of the same coverslip, at least four independent runs were conducted.

\section{Immunofluorescence}

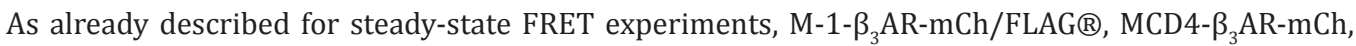
M-1-AVPR2-mCh or MCD4-AVPR2-mCh cells were treated with $10 \mu \mathrm{g} / \mathrm{ml}$ cycloheximide and stimulated for $1,3,6$ and $12 \mathrm{~h}$ with $10 \mathrm{nM}$ mirabegron or $100 \mathrm{nM}$ dDAVP, respectively. Cells treated with $10 \mu \mathrm{g} / \mathrm{ml}$ cycloheximide alone for 30 min were considered as resting condition. Cell monolayers were then fixed in PBS containing 4\% paraformaldehyde (M-1- $\beta_{3} \mathrm{AR}-\mathrm{mCh} / \mathrm{FLAG} \circledast$ and $\mathrm{M}-1-\mathrm{AVPR} 2-\mathrm{mCh}$ cells) or methanol (MCD4- $\beta_{3} \mathrm{AR}-\mathrm{mCh}$ and MCD4-AVPR2-mCh cells) and washed twice with PBS. Cells were blocked with 1\% BSA in PBS, then anti- $\mathrm{Na}^{+} / \mathrm{K}^{+}$-ATPase $\alpha-1$ antibody and anti-FLAG ${ }^{\circledR}$ (for M-1- $\beta_{3}$ AR-mCh/FLAG ${ }^{\circledR}$ and M-1AVPR2-mCh) or anti-AQP2 antibody (for MCD4- $\beta_{3} A R-m C h$ and MCD4-AVPR2-mCh cells) were incubated for $2 \mathrm{~h}$ at room temperature. The bound antibodies was detected with Alexa Fluor secondary antibodies (www.thermofisher.com). Images were acquired with a Leica TCS-SP2 confocal microscope (www.leicamicrosystems.com).

\section{Western blotting}

These experiments were performed in presence of $10 \mu \mathrm{g} / \mathrm{ml}$ cycloheximide, as reported above. M-1$\beta_{3} \mathrm{AR}-\mathrm{mCh}$ and M-1-AVPR2-mCh cells grown in 6-well culture plates were either left under basal condition or treated for $1,3,6,12$ and $24 \mathrm{~h}$ at $37^{\circ} \mathrm{C}$ with $10 \mathrm{nM}$ mirabegron or $100 \mathrm{nM}$ dDAVP, respectively. Cells were washed twice with ice-cold PBS w/o $\mathrm{Ca}^{2+}$ and $\mathrm{Mg}^{2+}$ and scraped into RIPA buffer $(150 \mathrm{mM} \mathrm{NaCl}, 10 \mathrm{mM}$ Tris, pH 7.2, $0.1 \%$ SDS, $1 \%$ Triton X-100, 1\% deoxycholate, 5 mM EDTA) containing protease and phosphatase inhibitors ( $1 \mathrm{mmol} / \mathrm{l}$ phenylmethylsulfonyl fluoride, $10 \mathrm{mmol} / \mathrm{l}$ leupeptin, $1 \mathrm{mg} / \mathrm{ml}$ pepstatin A, $10 \mathrm{mmol} / \mathrm{l}$ $\mathrm{NaF}, 1 \mathrm{mmol} / \mathrm{l}$ sodium orthovanadate, and $15 \mathrm{mmol} / \mathrm{l}$ tetrasodium pyrophosphate). Lysates were then 


\section{Cellular Physiology Cell Physiol Biochem 2018;48:847-862 \begin{tabular}{l|l} 
and Biochemistry Published online: July 20, 2018 & $\begin{array}{l}\text { C } 2018 \text { The Author(s). Published by S. Karger AG, Basel } \\
\text { www.karger.com/cpb }\end{array}$
\end{tabular} \\ Milano et al.: $\mathrm{B}_{3}$ ar Desensitization in Renal Cells}

sonicated for 30 seconds at $4^{\circ} \mathrm{C}$ using a microprobe sonicator. Insoluble material was pelleted at $13,000 \mathrm{~g}$ for $30 \mathrm{~min}$ at $4^{\circ} \mathrm{C} .5 \mu \mathrm{g}$ of each supernatant was separated by standard SDS-PAGE using Mini-PROTEAN $®$ TGX Stain-Free ${ }^{\mathrm{TM}}$ Precast Gels Bio-Rad and analyzed by Western blotting as previously described [46]. Densitometry was performed using the Image $\mathrm{Lab}^{\mathrm{TM}}$ software (Bio-rad) bundled with ChemiDoc ${ }^{\mathrm{TM}}\left(\mathrm{Bio}^{\mathrm{R}} \mathrm{Rad}\right)$ imaging system, after normalization for the total protein loading using the Stain-Fre ${ }^{\mathrm{TM}}$ technology (BioRad) according to manufacturer's instructions.

\section{Results}

$\beta_{3} A R$ activation elevates intracellular cAMP levels, activates $P K A$ and increases $\mathrm{Ca}^{2+}$ in renal epithelial cells

At first, we studied the $\beta_{3} A R$ signaling in M-1 cells stably expressing the receptor tagged with mCherry (M-1- $\beta_{3} A R-m C h$, Fig. $\left.1 A\right)$. $\beta_{3} A R$ is mainly localized on the plasma membrane, thus putatively able to sense and respond to extracellular stimuli. Thus, to asses $\beta_{3} \mathrm{AR}$ intracellular signaling, we evaluated cAMP generation and PKA activity in M-1- $\beta_{3} A R-m C h$ cells by expressing, either the cytosolic cAMP sensor Epac H96 [38] or the PKA activity probe AKAR4 [39], respectively. Both sensors are FRET-based, however, while Epac H96 works on the principle of "loss of FRET" and its FRET ratio decreases in response to cAMP elevation, AKAR4 works based on "gain of FRET" and reaches maximum FRET ratio when PKA activity is high [47]. Fig. 1 shows that treatment with $10 \mathrm{nM}$ mirabegron, a selective human $\beta_{3} \mathrm{AR}$ agonist, induced a decrease in the FRET ratio of H96 (Fig. 1B) and a parallel increase in the FRET ratio of AKAR4 (Fig. 1C), indicating increases of both cAMP level and PKA activity only in M-1- $\beta_{3}$ AR-mCh cells (white triangles) compared to untransfected cells (black diamonds).

In addition, we investigated whether mirabegron triggers $\mathrm{Ca}^{2+}$ oscillations. Fig. 1D shows the simultaneous time courses of the normalized Fura- 2 Ratio in four M-1- $\beta_{3} A R-m C h$ cells of the same coverslip. Stimulation with $10 \mathrm{nM}$ mirabegron induced not synchronous $\mathrm{Ca}^{2+}$ transients with different amplitudes and oscillatory frequencies.

Dose-dependent response to Mirabegron of $M-1-\beta_{3} A R$-mCh cells

Epac H96 was also used in steady-state FRET experiments to determine the lowest dose of mirabegron able to induce a significant cAMP production in M-1- $\beta_{3}$ AR-mCh cells (Fig. 2A).

Fig. 1. $\beta_{3} \mathrm{AR}$ intracellular signaling measured using FRETbased reporters and Fura-2. A) Confocal images of M-1 cells stably expressing $\beta_{3}$ AR-mCh. B) M-1 cells either expressing $\beta_{3}$ AR-mCh (withe triangles) or not (black diamonds) were transfected with Epac H96 and stimulated with mirabegron 10 nM. Traces represent data from 5-8 cells of the same coverslip. Data are expressed as means \pm SEM. C) M-1 cells either expressing $\beta_{3} \mathrm{AR}$ (withe triangles) or not (black diamonds) were transfected with AKAR4 and stimulated with mirabegron $10 \mathrm{nM}$. Traces

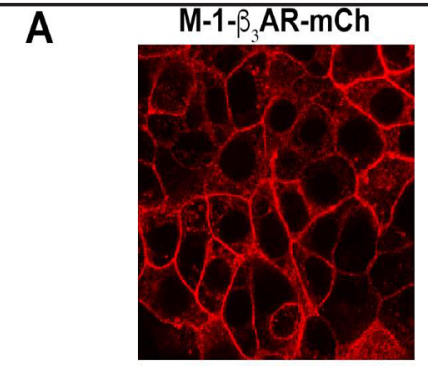

C

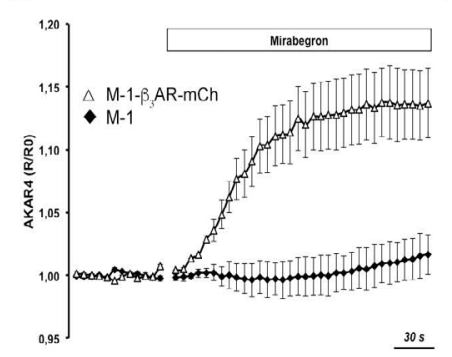

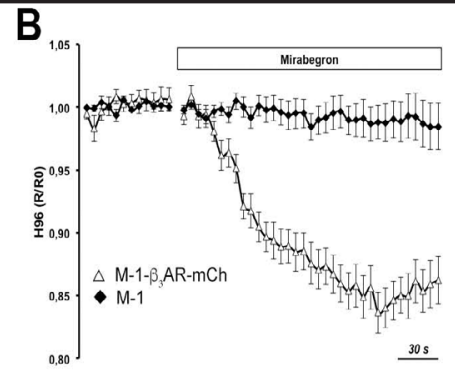

D

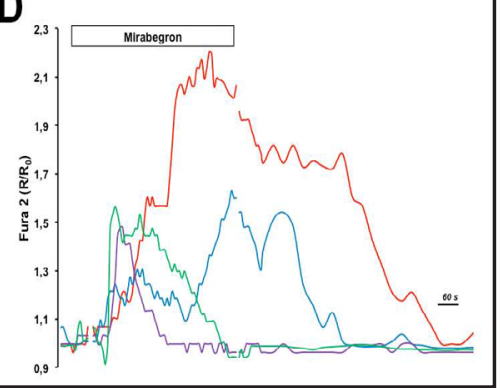
represent data from $5-8$ cells of the same coverslip. Data are expressed as means \pm SEM. D) Normalized time course of Fura-2 excitation ratio from four different $\mathrm{M}-1-\beta_{3} \mathrm{AR}-\mathrm{mCh}$ cells after exposure to $10 \mathrm{nM}$ mirabegron. 


\section{Cellular Physiology Cell Physiol Biochem 2018;48:847-862 \begin{tabular}{c|c} 
DOI: 10.1159/000491916 & $\begin{array}{l}\text { O 2018 The Author(s). Published by S. Karger AG, Basel } \\
\text { www.karger.com/cpb }\end{array}$
\end{tabular} \\ Milano et al.: $\mathrm{B}_{3}$ ar Desensitization in Renal Cells}

Fig. 2. Dose-response curves of mirabegron in $\mathrm{M}-1-\beta_{3} \mathrm{AR}-\mathrm{mCh}$ and dDAVP in M-1-AVPR2-mCh cells determined by Steady-state FRET. A) M-1$\beta_{3}$ AR-mCh and B) M-1-AVPR2-mCh cells were transfected with Epac $\mathrm{H} 96$ and stimulated for $1 \mathrm{~h}$ at $37^{\circ} \mathrm{C}$ with $1 \mathrm{nM}, 10 \mathrm{nM}, 100 \mathrm{nM}$ and $1 \mu \mathrm{M}$ mirabegron or dDAVP, respectively. cAMP levels inversely correlate with netFRET signals. Data from 15 different fields each one containing at least
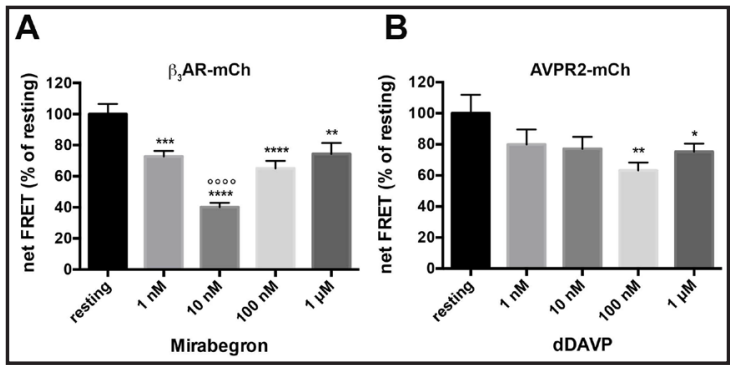
3 cells were summarized for a single coverslip/ treatment, and at least three independent coverslips were blind-analyzed. Averaged netFRET values from the different experimental conditions were expressed as percentage of the resting cells. Unpaired data were assessed for statistical significance using the Student's t test. Data are expressed as means \pm SEM. *p $<0.05$; ${ }^{* *} \mathrm{p}<0.01 ;{ }^{* * *} \mathrm{p}<0.001 ;{ }^{* * * *} \mathrm{p}<0.0001 .{ }^{0000} \mathrm{p}<0.0001$ ( $1 \mathrm{nM}$ vs $\left.10 \mathrm{nM}\right)$.

One-hour exposure to mirabegron (1 nM, $10 \mathrm{nM}, 100 \mathrm{nM}$ or $1 \mu \mathrm{M})$ induced a significant cAMP production, when compared to unstimulated cells, for all the tested doses. $10 \mathrm{nM}$ was the lower dose inducing maximal cAMP generation. Accordingly, we used $10 \mathrm{nM}$ mirabegron throughout this study.

Parallel experiments were performed in M-1-AVPR2-mCh cells to evaluate the minimum effective dose of dDAVP, a selective AVPR2 agonist. Fig. 2B shows that intracellular cAMP levels did not significantly change after treatment with $1 \mathrm{nM}$ and $10 \mathrm{nM}$ dDAVP while cAMP production was maximal upon exposure to $100 \mathrm{nM}$ dDAVP, as already reported [32, 48, 49], which was hence the concentration used for all the following experiments.

\section{Sustained receptor stimulation does not turn off the $\beta_{3}$ AR signaling}

Next, we evaluated if long-term exposure to mirabegron desensitizes $\beta_{3} \mathrm{AR}$ in term of cAMP signaling in M-1- $\beta_{3}$ AR-mCh cells expressing Epac H96. We calculated steady state netFRET changes as index of the cAMP production induced by mirabegron over different time points $(1,3,6,12$ and 24 hours). All experiments were performed in presence of cycloheximide to inhibit protein synthesis and thus excluding the potential contribution of newly synthesized receptors to cAMP production.

Compared to resting cells (cycloheximide, Fig. 3A), the netFRET signal was significantly reduced (of about a 30\%) in M-1- $\beta_{3} A R-m C h$ cells treated with mirabegron for $1 \mathrm{~h}$, indicating cAMP generation. This significant decrease of netFRET was also observed in cells exposed to mirabegron up to 12 hours. These findings indicate long-term, continuous cAMP signaling in the presence of mirabegron and suggest that no $\beta_{3}$ AR desensitization occurred within 12 $h$. To check whether this sustained response could be an artifact due to the presence of the mCherry tag, we repeated the same experiment in M-1 cells transiently transfected with FLAG ${ }^{\circ}-\beta_{3} A R\left(M-1-\beta_{3} A R-F L A G ®\right.$, Fig. $\left.3 B\right)$. The results obtained with the two $\beta_{3}$ AR constructs were overlapping.

Parallel experiments performed on M-1-AVPR2-mCh cells showed that $1 \mathrm{~h}$ exposure to dDAVP elicited a significant reduction in netFRET when compared to untreated cells (cycloheximide, Fig. 3C). This netFRET reduction was of the same extent of that induced by mirabegron in M-1- $\beta_{3}$ AR-mCh/ FLAG ${ }^{\circledR}$ cells, indicating similar cAMP signaling after $1 \mathrm{~h}$ of agonist exposure in both cell lines. However, dDAVP stimulation longer that $1 \mathrm{~h}$ did not induce any significant netFRET reduction. This evidence likely suggested that $\beta_{3} \mathrm{AR}$ was less prone than AVPR2 to undergo long-term agonist-induced desensitization in renal collecting duct.

Plasma membrane localization of $\beta_{3} A R$ under chronic agonist stimulation in renal epithelial cells

Next, we analyzed the cellular distribution of the receptor in M-1- $\beta_{3} \mathrm{AR}-\mathrm{mCh}$ cells upon chronic stimulation with mirabegron in the presence of cycloheximide to exclude 


\section{Cellular Physiology Cell Physiol Biochem 2018;48:847-862 \begin{tabular}{l|l|l} 
DOI: 10.1159/000491916 & $\begin{array}{l}\text { O 2018 The Author(s). Published by S. Karger AG, Basel } \\
\text { www.karger.com/cpb }\end{array}$
\end{tabular} \\ Milano et al.: $\mathrm{B}_{3}$ ar Desensitization in Renal Cells}

Fig. 3. Long-term exposure to the agonist does not desensitize $\beta_{3} \mathrm{AR}$ whereas turns off the AVPR2 response. A) M-1- $\beta_{3}$ AR-mCh cells were treated for $30 \mathrm{~min}$ with cycloheximide and next were either left under basal condition (10 $\mathrm{\mu g} / \mathrm{ml}$ cycloheximide) or treated with cycloheximide at $37^{\circ} \mathrm{C}$ with $10 \mathrm{nM}$ mirabegron for 1,3 ,6, 12 and $24 \mathrm{~h}$. Steady state FRET experiments performed with Epac H96 demonstrate that long-term exposure to mirabegron promoted a significant increase in intracellular cAMP for up to 12 hours. B) M-1 cells transiently transfected with FLAG $\AA$-tagged human $\beta_{3}$ AR (M-1- $\beta_{3}$ AR-FLAG $\AA$ ) were treated for 30 min with cycloheximide, then were either left under basal condition $(10 \mu \mathrm{g} / \mathrm{ml}$ cycloheximide) or treated at $37^{\circ} \mathrm{C}$ with $10 \mathrm{nM}$ mirabegron for 1, 3,6 and $12 \mathrm{~h}$ in the presence cycloheximide. Steady state FRET experiments performed with Epac $\mathrm{H} 96$ demonstrated that long-term stimulation induced a significant increase in intracellular cAMP for up to 12 hours. C) M-1-AVPR2-mCh cells were treated as in A) with dDAVP and intracellular cAMP was measured. dDAVP long-term stimulation induced short-lasting AVPR2 signaling not longer than $1 \mathrm{~h}$. Averaged netFRET values from the different experimental conditions were expressed as percentage of the resting cells at each time points. Comparable results were obtained in 3 different experiments and significance calculated by the Student's t test for unpaired data. Data are expressed as means \pm SEM. ${ }^{*} \mathrm{p}<0.05 ;{ }^{* *} \mathrm{p}<0.01 ;{ }^{* * *} \mathrm{p}<0.001 ;{ }^{* * * *} \mathrm{p}<$

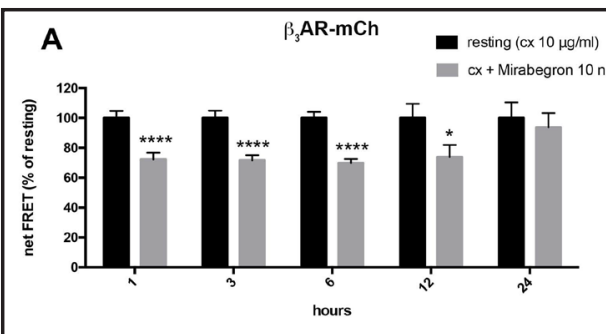

B
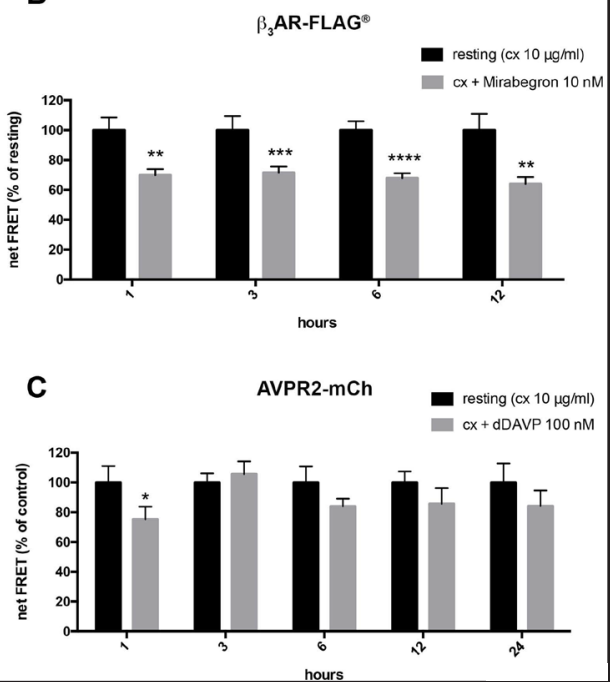
0.0001 .

Fig. 4. Cellular localization of $\beta_{3} A R$ under chronic agonist stimulation in renal epithelial cells. M-1$\beta_{3} \mathrm{AR}-\mathrm{mCh}$ cells were treated for $30 \mathrm{~min}$ with $10 \mu \mathrm{g} /$ $\mathrm{ml}$ cycloheximide (resting) or stimulated with $10 \mathrm{nM}$ mirabegron for $1,3,6$ and 12 hours in presence of $10 \mu \mathrm{g} / \mathrm{ml}$ cycloheximide. $\beta_{3} \mathrm{AR}$ (red) localization was analyzed directly using confocal microscopy. $\mathrm{Na}^{+} /$ $\mathrm{K}^{+}$-ATPase (green) was used as plasma membrane marker. Mirabegron stimulation produced very little effect on the subcellular distribution of $\beta_{3} \mathrm{AR}$. $\beta_{3} \mathrm{AR}$ predominantly colocalized at the basolateral plasma membrane with $\mathrm{Na}^{+} / \mathrm{K}^{+}$-ATPase in resting condition and after $1 \mathrm{~h}$ of exposure to mirabegron. After 3 and 6 hours of stimulation, $\beta_{3} \mathrm{AR}$ was predominantly localized at the plasma membrane and appeared in some intracellular vesicles. Remarkably, even $12 \mathrm{~h}$ after agonist exposure, $\beta_{3}$ AR membrane localization was still partially preserved. Scale bars, $20 \mu \mathrm{m}$.

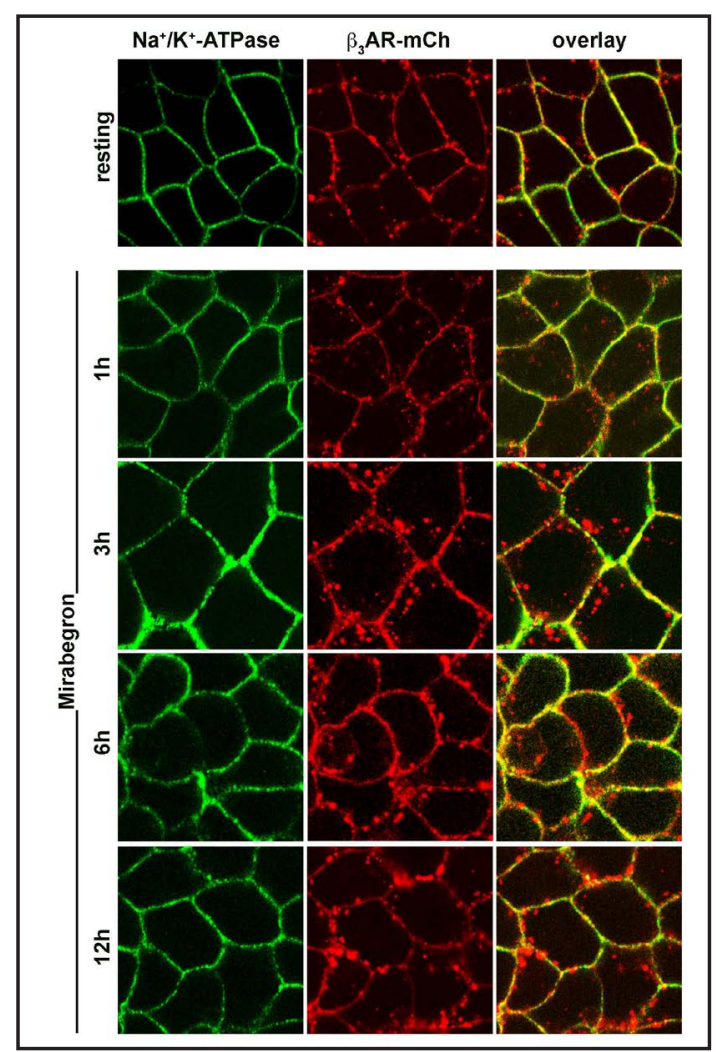




\section{Cellular Physiology Cell Physiol Biochem 2018;48:847-862 \begin{tabular}{c|c} 
DOI: 10.1159/000491916 & $\begin{array}{l}\text { O 2018 The Author(s). Published by S. Karger AG, Basel } \\
\text { www.karger.com/cpb }\end{array}$
\end{tabular}

the contribution of newly synthesized receptor (Fig. 4). Confocal microscopy experiments showed that at rest, $\beta_{3} \mathrm{AR}$ was mainly localized at the basolateral plasma membrane where it largely colocalized with the plasma membrane marker $\mathrm{Na}^{+} / \mathrm{K}^{+}$-ATPase. After $1 \mathrm{~h}$ stimulation with mirabegron, no apparent receptor internalization was observed since $\beta_{3} A R$ still largely co-localized with $\mathrm{Na}^{+} / \mathrm{K}^{+}$ATPase. At later time points of continuous mirabegron stimulation (3, 6 and $12 \mathrm{~h})$, a modest internalization of the receptor into a cytosolic punctate pattern appeared. However, $\beta_{3} \mathrm{AR}$ was still predominantly localized at the basolateral plasma membrane, even after $12 \mathrm{~h}$ of exposure to mirabegron. To check whether the reduced endocytosis could be explained by the presence of the mCherry tag, we repeated the same experiment with $\mathrm{M}-1-\beta_{3} \mathrm{AR}-$ FLAG® (Fig. 5). The results obtained with the two $\beta_{3} A R$ tags were overlapping.

In parallel experiments, we analyzed the receptor membrane trafficking in M-1AVPR2-mCh cells. We found that under basal conditions, the AVPR2 was mostly localized at the plasma membrane. In contrast, as shown in Fig. 6, exposure to dDAVP caused a robust and time-dependent internalization of AVPR2, as evidenced by appearance of packed cytoplasmic vesicles (Fig. 6). These effects were already observed at $1 \mathrm{~h}$ of incubation with dDAVP.

Receptor internalization was more dramatic at later time points and most of the receptors localized within cytoplasmic vesicles rather than at the plasma membrane. In addition, 12 $\mathrm{h}$ of continuous exposure to dDAVP led to a strong reduction of AVPR2 signal, probably indicating receptor degradation.

These findings indicated that, unlike AVPR2, $\beta_{3} A R$ did not internalize under chronic agonist stimulation in renal epithelial cells.

Long-term receptor stimulation causes delayed downregulation of $\beta_{3} A R$ protein in renal collecting duct epithelial cells

Long-term exposure to agonists can cause receptor downregulation, which is characterized by the depletion of the cellular receptor content due to alterations in the rate of receptor degradation and/or synthesis [12]. Here, Western blot experiments were performed in the presence of cycloheximide.

As shown in Fig. 7A anti-mCherry antibodies revealed a band of about $70 \mathrm{kDa}$ for the chimeric $\beta_{3}$ AR-mCh. Compared to resting cells (cycloheximide alone), comparable levels of the receptor were observed at 1 and $3 \mathrm{~h}$, while a small reduction of $\beta_{3} \mathrm{AR}-\mathrm{mCh}$ (of about $20 \%$ ) was observed at 6 and $12 \mathrm{~h}$ of continuous receptor activation (Fig. 7B). These results likely indicated that $\beta_{3}$ AR-mCh expression was slightly affected by long-term exposure to mirabegron up to 12 hours. Indeed, chronic exposure to mirabegron induced about $70 \%$ of receptor downregulation only after $24 \mathrm{~h}$ (Fig. 7B). 


\section{Cellular Physiology Cell Physiol Biochem 2018;48:847-862 \begin{tabular}{l|l} 
DOI: 10.1159/000491916 & $\begin{array}{l}\text { O 2018 The Author(s). Published by S. Karger AG, Basel } \\
\text { www.karger.com/cpb }\end{array}$
\end{tabular}

Fig. 6. Cellular localization of AVPR2 under chronic agonist stimulation in renal epithelial cells. M-1AVPR2-mCh cells were treated for 30 min with 10 $\mu \mathrm{g} / \mathrm{ml}$ cycloheximide (resting) or stimulated with $100 \mathrm{nM}$ dDAVP 1, 3, 6 and 12 hours in presence of 10 $\mu \mathrm{g} / \mathrm{ml}$ cycloheximide. AVPR2 (red) localization was analyzed directly using confocal microscopy. $\mathrm{Na}^{+}$/ $\mathrm{K}^{+}$-ATPase (green) was used as plasma membrane marker. Already after $1 \mathrm{~h}$ dDAVP, AVPR2 was internalized. At 3 and 6 hours after dDAVP exposure AVPR2 was lost from the plasma membrane and at $12 \mathrm{~h}$ receptor membrane staining was strongly reduced, probably because the sustained stimulation of AVPR2 induced receptor degradation. Images are representative of 3 independent experiments. Scale bars, $20 \mu \mathrm{m}$.

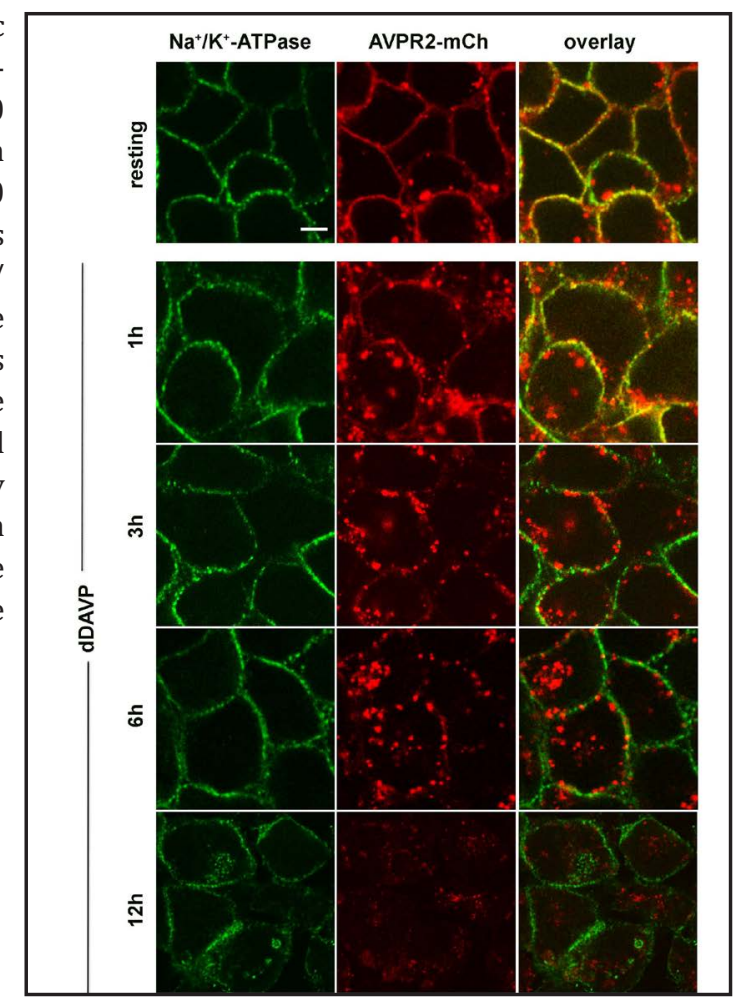

Fig. 7. Effect of long-term agonist stimulation on $\beta_{3} \mathrm{AR}$ and AVPR2 expression levels. M-1- $\beta_{3} A R-m C h$ and M-1-AVPR2-mCh cells were either left under resting condition $(10 \mu \mathrm{g} / \mathrm{ml}$ cycloheximide alone; first lane of each blot) or stimulated at $37^{\circ} \mathrm{C}$ with $10 \mathrm{nM}$ mirabegron (A) or $100 \mathrm{nM}$ dDAVP (C) for $1,3,6,12$ and 24 hours in presence of $10 \mu \mathrm{g} / \mathrm{ml}$ cycloheximide. Cells were lysed and subjected to Western blot analysis to detect, using anti-mCherry antibodies, the expression levels of $\beta_{3} \mathrm{AR}$ or AVPR2 normalized to total lane protein levels using the StainFree $^{\mathrm{TM}}$ gels technology. A) Western

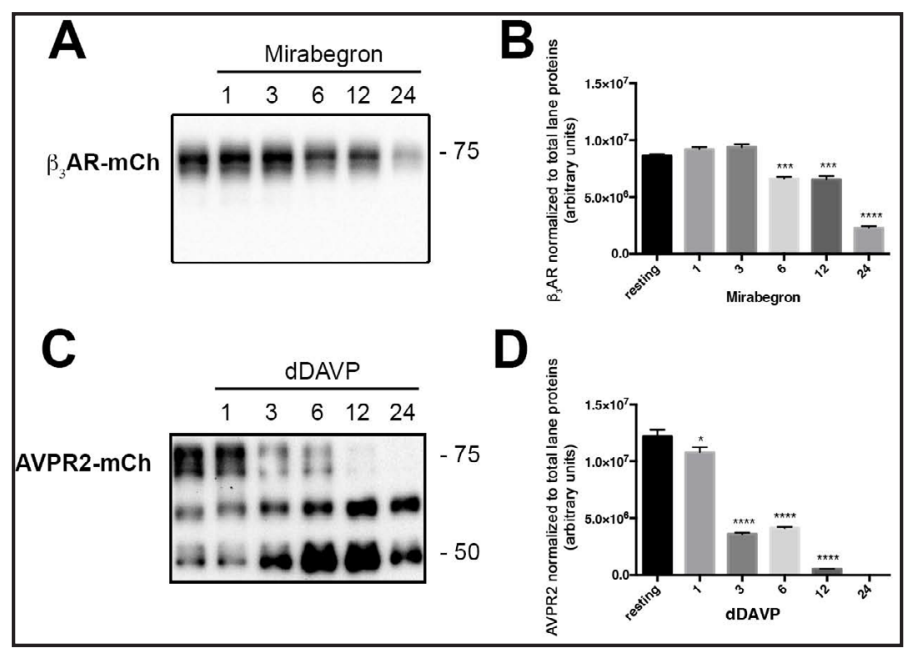
blotting with anti-mCherry antibodies revealed a band of about $70 \mathrm{kDa}$ for the chimeric $\beta_{3} \mathrm{AR}-\mathrm{mCh}$. B) Densitometric analysis of $\beta_{3} \mathrm{AR}$ bands, normalized to total lane proteins, showed no significant differences between resting cells and after 1 and 3 hours of mirabegron treatment. A small reduction of $\beta_{3}$ AR (of about 20\%) was observed at 6 and 12 h of continuous receptor activation. Mirabegron induced about 70\% of receptor downregulation only after 24 $\mathrm{h}$. The experiment was repeated three times and comparable results were obtained. Data are provided as mean \pm SEM. ${ }^{* * *} \mathrm{P}<0.001 ;{ }^{* * * *} \mathrm{P}<0.0001$. C) Western blotting with anti-mCherry antibodies revealed a broad smear around $70 \mathrm{kDa}$ band for the mature form of the chimeric AVPR2. Lower bands between 70 and 50 $\mathrm{kDa}$ likely represent degradation products of the receptor. D) Densitometric analysis of AVPR2 mature form, normalized to total lane proteins, showed a strong reduction of about $70 \%$ even after $3 \mathrm{~h}$ exposure to dDAVP and increased at 6 and $12 \mathrm{~h}$. At $24 \mathrm{~h}$ of dDAVP stimulation the mature form of AVPR2 was undetectable. On the contrary, the intensity of the lower molecular mass bands, likely representing degradation products of AVPR2, was increased in a time-dependent manner. These results are representative of 3 independent experiments. Data are provided as mean \pm SEM. ${ }^{*} \mathrm{P}<0.05 ;{ }^{* * * *} \mathrm{P}<0.0001$. 


\section{Cellular Physiology Cell Physiol Biochem 2018;48:847-862 \begin{tabular}{l|l} 
DOI: 10.1159/000491916 & O 2018 The Author(s). Published by S. Karger AG, Basel \\
www.kargercom/cpb
\end{tabular} Milano et al.: $\mathrm{B}_{3}$ ar Desensitization in Renal Cells}

Conversely, in M1-AVPR2-mCh cells, the anti-mCherry antibody revealed a broad smear around $70 \mathrm{kDa}$ and lower bands between 70 and $50 \mathrm{kDa}$ (Fig. 7C). In presence of dDAVP, the intensity of higher molecular mass bands, representing the mature form of the protein, was reduced in a time-dependent manner. As reported in Fig. 7D, a strong reduction of about 70\% was clearly evident even after $3 \mathrm{~h}$ exposure to dDAVP and increased at later time points ( 6 and $12 \mathrm{~h}$ ). At $24 \mathrm{~h}$ of stimulation with dDAVP the mature form of the receptor was undetectable while the intensity of the lower molecular mass bands, likely representing degradation products of AVPR2, was greatly increased, thus suggesting complete degradation of AVPR2.

These finding indicates that $\beta_{3} \mathrm{AR}$ was resistant to degradation up to $12 \mathrm{~h}$ of continuous exposure to the agonist.

\section{$\beta_{3} A R$ activation promotes apical AQP2 expression in renal epithelial cells}

In renal collecting duct cells, cAMP levels are fundamental regulators of AQP2 translocation to the apical plasma membrane [46]. Therefore, the fact that $\beta_{3} A R$ chronic stimulation sustains persistent high levels of cytosolic cAMP should be taken into account when considering AQP2 translocation. Thus, we investigated the effect of long-term $\beta_{3} A R$ activation on AQP2 trafficking in MCD4 cells, a clone of M-1 cells that stably express humanAQP2 [50]. These cells were stably transfected with the cDNA that encodes either $\beta_{3} \mathrm{AR}-\mathrm{mCh}$ or AVPR2-mCh.

Fig. 8A reports the confocal analysis of AQP2 localization in MCD4- $\beta_{3} A R-m C h$ resting cells after treatment with mirabegron for 1, 3, 6, 12 hours. The cAMP-elevating agent forskolin (FK) was used as positive control for its ability to promote AQP2 exocytosis. AQP2 staining was imaged in a xy confocal plan, passing through the cell apical membrane (upper panel) and in the xz confocal plan. In unstimulated MCD4- $\beta_{3} A R-m C h$ cells (cycloheximide alone), most of the AQP2 was located in intracellular and sub-apical vesicles. $1 \mathrm{~h}$ mirabegron treatment

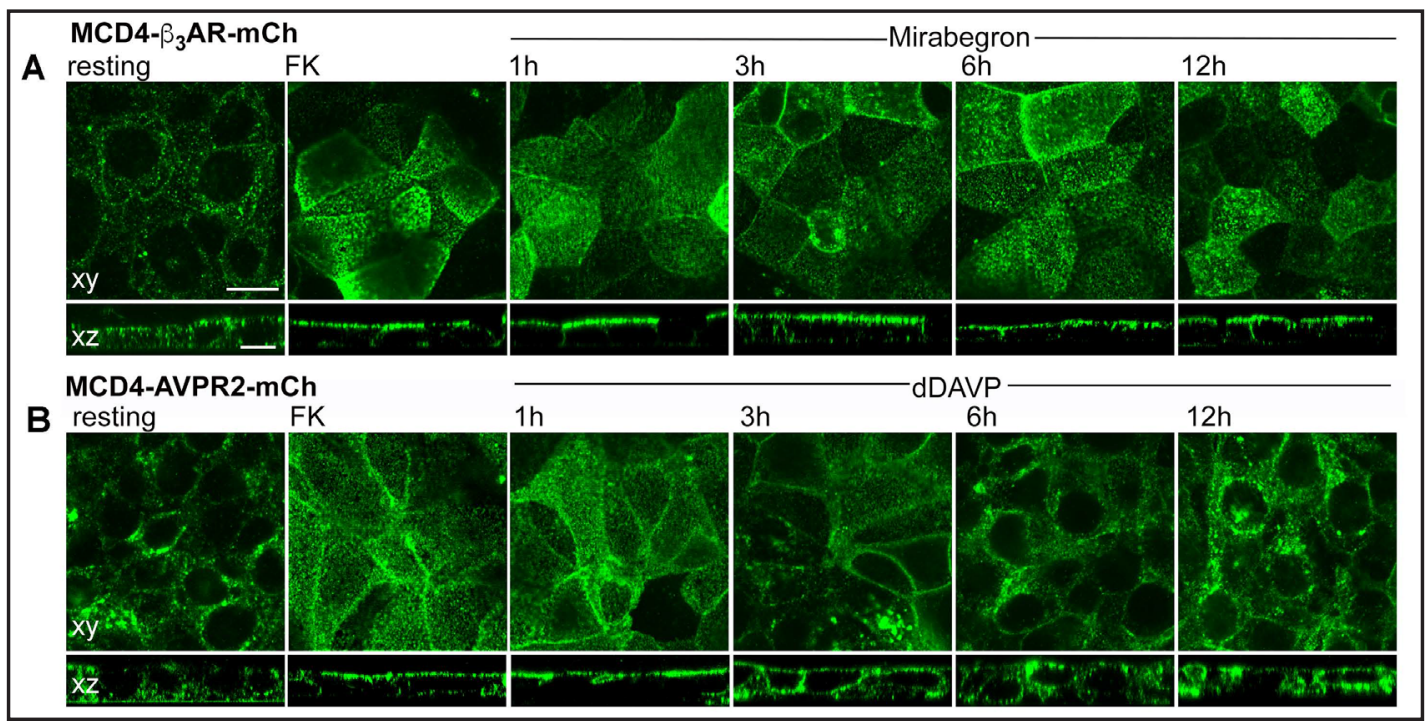

Fig. 8. $\beta_{3} \mathrm{AR}$ stimulation promotes apical $\mathrm{AQP} 2$ expression in renal epithelial cells. Confocal immunofluorescence analysis of AQP2 subcellular localization in MCD4 renal cells stably transfected with $\beta_{3}$ AR (MCD4- $\beta_{3}$ AR-mCh) or AVPR2 (MCD4-AVPR2-mCh) in resting condition, after $100 \mu \mathrm{M}$ FK stimulation, and after incubation with $10 \mathrm{nM}$ mirabegron or $100 \mathrm{nM}$ dDAVP, respectively. AQP2 immunostaining was visualized in the xy apical confocal plan (upper panels) and in the xz confocal plan (lower panels). A) Compared to resting conditions, mirabegron, like FK, redistributed AQP2 to the apical plasma membrane. AQP2 translocation induced by mirabegron was clearly evident also after $12 \mathrm{~h}$ of continuous stimulation. B) The effect of dDAVP on AQP2 apical expression occurred at 1 and $3 \mathrm{~h}$ but at 6 and $12 \mathrm{~h} \mathrm{AQP2}$ was localized in intracellular vesicles. Pictures are representative of at least three independent experiments. Scale bars, $20 \mu \mathrm{m}$. 


\section{Cellular Physiology Cell Physiol Biochem 2018;48:847-862 \\ \begin{tabular}{l|l} 
DOI: 10.1159/000491916 & O 2018 The Author(s). Published by S. Karger AG, Basel \\
www.karger.com/cpb
\end{tabular} \\ Milano et al.: $\mathrm{B}_{3}$ ar Desensitization in Renal Cells}

resulted in AQP2 redistribution to the apical plasma membrane similar to that obtained by maximal FK stimulation. Interestingly, even at 12 hours of continuous stimulation of $\beta_{3} \mathrm{AR}$ with mirabegron AQP2 was still exposed at the apical plasma membrane clearly indicating that $\beta_{3} \mathrm{AR}$ intracellular signaling is not switched off. These results were consistent with our findings on persistent increase of intracellular cAMP, slow internalization and delayed downregulation of $\beta_{3} \mathrm{AR}$ in $\mathrm{M}-1$ cells.

On the contrary, the effect of dDAVP on AQP2 translocation in MCD4-AVPR2-mCh cells was observed within $3 \mathrm{~h}$ (Fig. 8B). As described previously in this study, this evidence was due to a short-lasting cAMP signaling, rapid internalization and downregulation of AVPR2 which already occurred at 3 hours of dDAVP stimulation.

\section{Discussion}

Maintaining water homeostasis lies in the ability of the kidneys to concentrate urine and can be mainly attributed to the AVP/AVPR2/AQP2 axis [51]. Under physiological conditions, excessive loss of water through the urine is prevented by the AVP which promotes the osmotic reabsorption of water in the collecting ducts. In kidney collecting duct principal cells, the binding of AVP to basolateral AVPR2 triggers the activation of adenylyl cyclase via Gos protein, with generation of cAMP that in turn activates protein kinase A (PKA). Consequently, the AQP2 is phosphorylated and translocated from a pool of intracellular storage vesicles to the apical plasma membrane of the principal cells, where it highly increases membrane permeability promoting water reabsorption [52]. This process is reversed by a reduction in circulating AVP levels, which reflects the establishment of isotonicity.

Inactivating mutations of AVPR2 cause X-linked Nephrogenic Diabetes Insipidus (X-NDI). The lack of functional AVPR2 impairs both AQP2 trafficking to the plasma membrane and its transcription in X-NDI patients [53]. Therefore, the kidney loses its ability to concentrate urine leading to the production of large volumes of dilute urine.

Several studies suggested the possibility to restore proper water homeostasis in X-NDI by activating other Gs-coupled receptors expressed in the same renal cells expressing defective AVPR2 [5, 46, 54-56]. However, the potential use of the GPCR exploited so far, such as secretin [46], calcitonin [54] and EP4 $[55,56]$, is limited by their rapid desensitization [57-59].

In this respect, $\beta_{3} A R$ seems to be a promising drug target to promote antidiuresis bypassing AVPR2 signaling. $\beta_{3}$ AR is localized in the AVP-sensitive nephron segments and its activation by a single intraperitoneal injection of BRL3744 induces antidiuresis in mice lacking AVPR2 [5]. Since X-NDI is a congenital condition, long-term treatment with $\beta_{3}$ AR agonists may be considered as one of therapeutic possibilities. Thus, as a pre-requisite to predict the feasibility of future clinical trials, we first evaluated in vitro whether $\beta_{3} \mathrm{AR}$ is subject to desensitization upon chronic stimulation in renal cells.

Here, long-term desensitization was investigated with respect to receptor downstream signaling, internalization and degradation.

We first evaluated the signaling pathway through which $\beta_{3}$ AR signals in renal cells. In the present study, we showed that mirabegron-induced $\beta_{3} A R$ activation, elevated intracellular cAMP and activates PKA. These results are consistent with our recent study in which, in mouse kidney tubule suspensions, treatment with specific agonist for mouse $\beta_{3} \mathrm{AR}$ led to a concentration-dependent increase in intracellular cAMP [5]. In addition, we show that mirabegron induced not synchronous $\mathrm{Ca}^{2+}$ transients in kidney cells expressing $\beta_{3} \mathrm{AR}$. These results are in line with previous reports on the intracellular $\mathrm{Ca}^{2+}$ mobilization triggered by cAMP-mediated agonists, including AVP and dDAVP [60-63]. Furthermore, previous studies pointed out a key role for localized increases in intracellular $\mathrm{Ca}^{2+}$ concentration as trigger for the fusion of vesicles to their target membranes [16], as also reported for the AVP-dependent exocytotic insertion of AQP2 [63]. Thus, mirabegron-induced $\mathrm{Ca}^{2+}$ increases might be important for the fusion of AQP2 vesicles to the apical membranes.

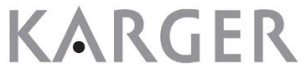




\section{Cellular Physiology Cell Physiol Biochem 2018;48:847-862

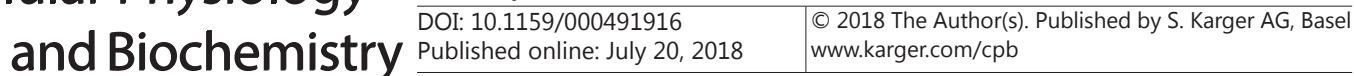 \\ Milano et al.: $\mathrm{B}_{3}$ ar Desensitization in Renal Cells}

In the present study, $\beta_{3} \mathrm{AR}$ showed preserved cAMP signaling even after $12 \mathrm{~h}$ of continuous agonist exposure. Different studies indicated that long-term activation of $\beta_{3} A R$ (up to $24 \mathrm{~h}$ ) induced adenylyl cyclase activity [14, 20] and cAMP signaling [19] that were, however, significantly reduced over the time course of the experiments. Considering the small amount of receptor internalization, the sustained increase in cAMP level under chronic activation of $\beta_{3} \mathrm{AR}$ is likely due to the functional receptor localized at the basolateral membrane and not within the endocytic pathway, as reported for other GPCRs $[48,64,65]$. In addition, the small reduction in the expression level of $\beta_{3} \mathrm{AR}$ after $6 \mathrm{~h}$ probably indicates that internalized $\beta_{3} A R$ undergoes degradation. Previous independent studies showed that, in chinese hamster fibroblasts (CHW) cells expressing $\beta_{3} \mathrm{AR}[17,66]$, the receptor density on the plasma membrane was unchanged after $24 \mathrm{~h}$ treatment with isoproterenol. However, both studies were performed in the absence of cycloheximide, thus membrane insertion of newly synthesized receptor cannot be excluded. However, these evidences seemed strictly dependent by the cell type since, under the same chronic stimulation, $\beta_{3} \mathrm{AR}$ was significantly reduced in murine L fibroblast cells and human neuroblastoma SK-N-MC cells $[66,67]$.

Overall, these findings strongly suggested that, at least in vitro, human $\beta_{3} A R$ is resistant to chronic agonist-induced desensitization in renal cells. Of note, this effect is not an artifact due to the presence of the large mCherry tag, since same results were also obtained with the small FLAG® tag (see Fig. 3B and 5).

In addition, we demonstrated that long-term $\beta_{3} A R$ stimulation with mirabegron, leading to persistent higher levels of cytosolic cAMP, keeps promoting AQP2 apical membrane expression up to $12 \mathrm{~h}$ in renal cells. The persistent effect on the AQP2 apical localization likely supports the hypothesis that chronic $\beta_{3} A R$ agonist use could be exploited to promote water reabsorption for the long time in vivo. It should be noted that $\beta_{3} \mathrm{AR}$ agonists are already approved by the American food and drug administration (FDA) and the European Medicines Agency (EMA) for the treatment of overactive bladder (OAB) and mirabegron is the first drug licensed for this use $[68,69]$. It is a safe, effective and well-tolerated new class of drug [7073]. Considering the expression of $\beta_{3} \mathrm{AR}$ in the heart, it has been demonstrated, by several studies, that mirabegron does not cause clinically relevant changes in cardiovascular safety [73].

In our study, parallel experiments regarding AVPR2 highlighted the substantial desensitization differences between AVPR2, selected by the evolution as the main mediator of the antidiuretic action in the kidney and $\beta_{3} \mathrm{AR}$, an alternative GPCR proposed to mimic AVPR2 effects.

We show here that AVPR2 was largely sequestrated within intracellular vesicles and strongly downregulated with no significant downstream signaling after $3 \mathrm{~h}$ exposure to dDAVP. In fact, physiological effects of AVPR2 are very rapid and promptly reversible [74]. Vasopressin has a very short biological half-life, about $3 \mathrm{~min}$ [74], and exhibit robust circadian oscillations increasing osmolality and decreasing volume of the urine during sleep to prevents nocturnal polyuria and sleep disruptions [75]. These mechanisms are likely preserved in X-NDI patients, although the absence of functional AVPR2 prevents a proper antidiuresis. Therefore, stimulation of another GPCR expressed in kidney principal cells, might circumvent the AVPR2 defect. Of note, $\beta_{3} A R$ is less prone than AVPR2 to agonist-induced desensitization in renal collecting duct epithelial cells and its chronic stimulation promoted a continuous effect on AQP2 apical expression. These findings encourage preclinical studies supporting the hypothesis that chronic $\beta_{3} \mathrm{AR}$ stimulation should promote effective antidiuresis in X-NDI patients.

\section{Disclosure Statement}

This work was supported by the Fondazione Telethon (project \# GGP15083) to M.S. The authors declare to have no conflict. 


\section{Cellular Physiology Cell Physiol Biochem 2018;48:847-862 \begin{tabular}{l|l} 
DOI: 10.1159/000491916 & O 2018 The Author(s). Published by S. Karger AG, Basel \\
www.karger.com/cpb
\end{tabular} \\ Milano et al.: $\mathrm{B}_{3}$ ar Desensitization in Renal Cells}

\section{References}

1 Tan S, Curtis-Prior PB: Characterization of the beta-adrenoceptor of the adipose cell of the rat. Int J Obes 1983;7:409-414.

-2 Arch JR, Ainsworth AT, Cawthorne MA, Piercy V, Sennitt MV, Thody VE, Wilson C, Wilson S: Atypical betaadrenoceptor on brown adipocytes as target for anti-obesity drugs. Nature 1984;309:163-165.

- 3 Emorine LJ, Marullo S, Briend-Sutren MM, Patey G, Tate K, Delavier-Klutchko C, Strosberg AD: Molecular characterization of the human beta 3-adrenergic receptor. Science 1989;245:1118-1121.

4 Ursino MG, Vasina V, Raschi E, Crema F, De Ponti F: The beta3-adrenoceptor as a therapeutic target: current perspectives. Pharmacol Res 2009;59:221-234.

-5 Procino G, Carmosino M, Milano S, Dal Monte M, Schena G, Mastrodonato M, Gerbino A, Bagnoli P, Svelto M: beta3 adrenergic receptor in the kidney may be a new player in sympathetic regulation of renal function. Kidney Int 2016;90:555-567.

6 Bockenhauer D, Bichet DG: Pathophysiology, diagnosis and management of nephrogenic diabetes insipidus. Nat Rev Nephrol 2015;11:576-588.

7 Wesche D, Deen PM, Knoers NV: Congenital nephrogenic diabetes insipidus: the current state of affairs. Pediatr Nephrol 2012;27:2183-2204.

8 Giuseppe Procino SMMCAGLBPP, Maria S: Hereditary Nephrogenic Diabetes Insipidus: Molecular Basis of the Defect and Potential Novel Strategies for Treatment. J Genet Syndrom Gen Therap 2014;5:1-14.

-9 Milano S, Carmosino M, Gerbino A, Svelto M, Procino G: Hereditary Nephrogenic Diabetes Insipidus: Pathophysiology and Possible Treatment. An Update. Int J Mol Sci 2017;18

10 Hausdorff WP, Caron MG, Lefkowitz RJ: Turning off the signal: desensitization of beta-adrenergic receptor function. FASEB J 1990;4:2881-2889.

11 Bohm SK, Grady EF, Bunnett NW: Regulatory mechanisms that modulate signalling by G-protein-coupled receptors. Biochem J 1997;322:1-18.

12 Grady EF, Bohm SK, Bunnett NW: Turning off the signal: mechanisms that attenuate signaling by G proteincoupled receptors. Am J Physiol 1997;273:G586-601.

13 Carpene C, Galitzky J, Collon P, Esclapez F, Dauzats M, Lafontan M: Desensitization of beta-1 and beta-2, but not beta-3, adrenoceptor-mediated lipolytic responses of adipocytes after long-term norepinephrine infusion. J Pharmacol Exp Ther 1993;265:237-247.

14 Chaudhry A, Granneman JG: Influence of cell type upon the desensitization of the beta 3-adrenergic receptor. J Pharmacol Exp Ther 1994;271:1253-1258.

15 Thomas RF, Holt BD, Schwinn DA, Liggett SB: Long-term agonist exposure induces upregulation of beta 3-adrenergic receptor expression via multiple cAMP response elements. Proc Natl Acad Sci U S A 1992;89:4490-4494.

16 Curran PK, Fishman PH: Endogenous $\beta 3$ - but not $\beta 1$-adrenergic receptors are resistant to agonist-mediated regulation in human SK-N-MC neurotumor cells. Cell Signal 1996;8:355-364.

17 Liggett SB, Freedman NJ, Schwinn DA, Lefkowitz RJ: Structural basis for receptor subtype-specific regulation revealed by a chimeric beta 3/beta 2-adrenergic receptor. Proc Natl Acad Sci U S A 1993;90:3665-3669.

-18 Nantel F, Bonin H, Emorine LJ, Zilberfarb V, Strosberg AD, Bouvier M, Marullo S: The human beta 3 -adrenergic receptor is resistant to short term agonist-promoted desensitization. Mol Pharmacol 1993;43:548-555.

19 Candelore MR, Deng L, Tota LM, Kelly LJ, Cascieri MA, Strader CD: Pharmacological characterization of a recently described human beta 3-adrenergic receptor mutant. Endocrinology 1996;137:2638-2641.

-20 Chambers J, Park J, Cronk D, Chapman C, Kennedy FR, Wilson S, Milligan G: Beta 3-adrenoceptor agonistinduced down-regulation of Gs alpha and functional desensitization in a Chinese hamster ovary cell line expressing a beta 3-adrenoceptor refractory to down-regulation. Biochem J 1994;303 ( Pt 3):973-978.

21 Nantel F, Bouvier M, Strosberg AD, Marullo S: Functional effects of long-term activation on human beta 2and beta 3-adrenoceptor signalling. Br J Pharmacol 1995;114:1045-1051.

-22 Bengtsson T, Redegren K, Strosberg AD, Nedergaard J, Cannon B: Down-regulation of beta3 adrenoreceptor gene expression in brown fat cells is transient and recovery is dependent upon a short-lived protein factor. J Biol Chem 1996;271:33366-33375. 


\section{Cellular Physiology Cell Physiol Biochem 2018;48:847-862 \begin{tabular}{l|l} 
DOI: 10.1159/000491916 & O 2018 The Author(s). Published by S. Karger AG, Basel \\
www.karger.com/cpb
\end{tabular} \\ Milano et al.: $B_{3}$ ar Desensitization in Renal Cells}

-23 Granneman JG, Lahners KN: Differential adrenergic regulation of beta 1- and beta 3-adrenoreceptor messenger ribonucleic acids in adipose tissues. Endocrinology 1992;130:109-114.

-24 Hutchinson DS, Evans BA, Summers RJ: beta(3)-adrenoceptor regulation and relaxation responses in mouse ileum. Br J Pharmacol 2000;129:1251-1259.

-25 Scarpace PJ, Matheny M, Tumer N: Differential down-regulation of beta3-adrenergic receptor mRNA and signal transduction by cold exposure in brown adipose tissue of young and senescent rats. Pflugers Arch 1999;437:479-483.

-26 Vrydag W, Alewijnse AE, Michel MC: Do gene polymorphisms alone or in combination affect the function of human beta3-adrenoceptors? Br J Pharmacol 2009;156:127-134.

-27 Seifert R: A door opener for future research: agonist-induced beta3-adrenoceptor desensitization in HEK cells but not CHO cells. Naunyn Schmiedebergs Arch Pharmacol 2013;386:841-842.

28 Sacco E, Bientinesi R: Mirabegron: a review of recent data and its prospects in the management of overactive bladder. Ther Adv Urol 2012;4:315-324.

29 Igawa Y, Michel MC: Pharmacological profile of beta3-adrenoceptor agonists in clinical development for the treatment of overactive bladder syndrome. Naunyn Schmiedebergs Arch Pharmacol 2013;386:177-183.

-30 Stoos BA, Naray-Fejes-Toth A, Carretero OA, Ito S, Fejes-Toth G: Characterization of a mouse cortical collecting duct cell line. Kidney Int 1991;39:1168-1175.

-31 Bouley R, Lin HY, Raychowdhury MK, Marshansky V, Brown D, Ausiello DA: Downregulation of the vasopressin type 2 receptor after vasopressin-induced internalization: involvement of a lysosomal degradation pathway. Am J Physiol Cell Physiol 2005;288:C1390-1401.

-32 Innamorati G, Sadeghi H, Eberle AN, Birnbaumer M: Phosphorylation of the V2 vasopressin receptor. The J Biol Chem 1997;272:2486-2492.

-33 Martin NP, Lefkowitz RJ, Shenoy SK: Regulation of V2 vasopressin receptor degradation by agonistpromoted ubiquitination. J Biol Chem 2003;278:45954-45959.

34 Robben JH, Knoers NV, Deen PM: Regulation of the vasopressin V2 receptor by vasopressin in polarized renal collecting duct cells. Mol Biol Cell 2004;15:5693-5699.

- 35 Tamma G, Procino G, Strafino A, Bononi E, Meyer G, Paulmichl M, Formoso V, Svelto M, Valenti G: Hypotonicity induces aquaporin-2 internalization and cytosol-to-membrane translocation of ICln in renal cells. Endocrinology 2007;148:1118-1130.

-36 Procino G, Barbieri C, Tamma G, De Benedictis L, Pessin JE, Svelto M, Valenti G: AQP2 exocytosis in the renal collecting duct -- involvement of SNARE isoforms and the regulatory role of Munc18b. J Cell Sci 2008;121:2097-2106.

37 Iolascon A, Aglio V, Tamma G, D’Apolito M, Addabbo F, Procino G, Simonetti MC, Montini G, Gesualdo L, Debler EW, Svelto M, Valenti G: Characterization of two novel missense mutations in the AQP2 gene causing nephrogenic diabetes insipidus. Nephron Physiology 2007;105:p33-41.

-38 van der Krogt GN, Ogink J, Ponsioen B, Jalink K: A comparison of donor-acceptor pairs for genetically encoded FRET sensors: application to the Epac cAMP sensor as an example. PLoS One 2008;3:e1916.

-39 Depry C, Allen MD, Zhang J: Visualization of PKA activity in plasma membrane microdomains. Mol Biosyst 2011;7:52-58.

40 Lefkimmiatis K, Moyer MP, Curci S, Hofer AM: “cAMP sponge”: a buffer for cyclic adenosine 3', 5'-monophosphate. PLoS One 2009;4:e7649.

-41 Procino G, Gerbino, A., Milano, S., Nicoletti, M. C., Mastrofrancesco, L., Carmosino, M., \& Svelto, M.: Rosiglitazone Promotes AQP2 Plasma Membrane Expression In Renal Cells Via a Ca2+-Dependent/cAMPIndipendent Mechanism. Cell Physiol Biochem 2015;35:15.

42 Post SR, Rump LC, Zambon A, Hughes RJ, Buda MD, Jacobson JP, Kao CC, Insel PA: ATP activates cAMP production via multiple purinergic receptors in MDCK-D1 epithelial cells. Blockade of an autocrine/ paracrine pathway to define receptor preference of an agonist. J Biol Chem 1998;273:23093-23097.

43 Deen PM, Rijss JP, Mulders SM, Errington RJ, van Baal J, van Os CH: Aquaporin-2 transfection of MadinDarby canine kidney cells reconstitutes vasopressin-regulated transcellular osmotic water transport. JASN 1997;8:1493-1501.

44 Gerbino A, Schena G, Milano S, Milella L, Barbosa AF, Armentano F, Procino G, Svelto M, Carmosino M: Spilanthol from Acmella Oleracea Lowers the Intracellular Levels of cAMP Impairing NKCC2 Phosphorylation and Water Channel AQP2 Membrane Expression in Mouse Kidney. PLoS One 2016;11:e0156021. 


\section{Cellular Physiology Cell Physiol Biochem 2018;48:847-862 \begin{tabular}{l|l} 
DOI: 10.1159/000491916 & Ond 2018 The Author(s). Published by S. Karger AG, Basel \\
www.karger.com/cpb
\end{tabular} \\ Milano et al.: $\mathrm{B}_{3}$ ar Desensitization in Renal Cells}

45 Carmosino M, Gerbino A, Hendy GN, Torretta S, Rizzo F, Debellis L, Procino G, Svelto M: NKCC2 activity is inhibited by the Bartter's syndrome type 5 gain-of-function CaR-A843E mutant in renal cells. Biol Cell 2015;107:98-110.

46 Procino G, Milano S, Carmosino M, Barbieri C, Nicoletti MC, Li JH, Wess J, Svelto M: Combination of secretin and fluvastatin ameliorates the polyuria associated with X-linked nephrogenic diabetes insipidus in mice. Kidney Int 2014;86:127-138.

47 Burdyga A, Lefkimmiatis K: Simultaneous assessment of cAMP signaling events in different cellular compartments using FRET-based reporters. Methods Mol Biol 2015;1294:1-12.

-48 Feinstein TN, Yui N, Webber MJ, Wehbi VL, Stevenson HP, King JD, Jr., Hallows KR, Brown D, Bouley R, Vilardaga JP: Noncanonical control of vasopressin receptor type 2 signaling by retromer and arrestin. J Biol Chem 2013;288:27849-27860.

49 Innamorati G, Le Gouill C, Balamotis M, Birnbaumer M: The long and the short cycle. Alternative intracellular routes for trafficking of G-protein-coupled receptors. J Biol Chem 2001;276:13096-13103.

50 Iolascon A, Aglio V, Tamma G, D’Apolito M, Addabbo F, Procino G, Simonetti MC, Montini G, Gesualdo L, Debler EW, Svelto M, Valenti G: Characterization of two novel missense mutations in the AQP2 gene causing nephrogenic diabetes insipidus. Nephron Physiol 2007;105:p33-41.

51 Juul KV: The evolutionary origin of the vasopressin/V2-type receptor/aquaporin axis and the urineconcentrating mechanism. Endocrine 2012;42:63-68.

52 Fushimi K, Sasaki S, Marumo F: Phosphorylation of serine 256 is required for cAMP-dependent regulatory exocytosis of the aquaporin-2 water channel. J biol chem 1997;272:14800-14804.

53 Matsumura Y, Uchida S, Rai T, Sasaki S, Marumo F: Transcriptional regulation of aquaporin-2 water channel gene by cAMP. J Am Soc Nephrol 1997;8:861-867.

54 Bouley R, Lu HA, Nunes P, Da Silva N, McLaughlin M, Chen Y, Brown D: Calcitonin has a vasopressin-like effect on aquaporin-2 trafficking and urinary concentration. J Am Soc Nephrol 2011;22:59-72.

$\rightarrow 55$ Li JH, Chou CL, Li B, Gavrilova O, Eisner C, Schnermann J, Anderson SA, Deng CX, Knepper MA, Wess J: A selective EP4 PGE2 receptor agonist alleviates disease in a new mouse model of X-linked nephrogenic diabetes insipidus. J Clin Invest 2009;119:3115-3126.

56 Olesen ET, Rutzler MR, Moeller HB, Praetorius HA, Fenton RA: Vasopressin-independent targeting of aquaporin-2 by selective E-prostanoid receptor agonists alleviates nephrogenic diabetes insipidus. Proc Natl Acad Sci U S A 2011;108:12949-12954.

57 Ozcelebi F, Holtmann MH, Rentsch RU, Rao R, Miller LJ: Agonist-stimulated phosphorylation of the carboxyl-terminal tail of the secretin receptor. Mol Pharmacol 1995;48:818-824.

- 58 Samura A, Wada S, Suda S, Iitaka M, Katayama S: Calcitonin receptor regulation and responsiveness to calcitonin in human osteoclast-like cells prepared in vitro using receptor activator of nuclear factor-kappaB ligand and macrophage colony-stimulating factor. Endocrinology 2000;141:3774-3782.

59 Nishigaki N, Negishi M, Ichikawa A: Two Gs-coupled prostaglandin E receptor subtypes, EP2 and EP4, differ in desensitization and sensitivity to the metabolic inactivation of the agonist. Mol Pharmacol 1996;50:1031-1037.

60 Chou CL, Yip KP, Michea L, Kador K, Ferraris JD, Wade JB, Knepper MA: Regulation of aquaporin-2 trafficking by vasopressin in the renal collecting duct. Roles of ryanodine-sensitive Ca2+ stores and calmodulin. J Biol Chem 2000;275:36839-36846.

-61 Ecelbarger CA, Chou CL, Lolait SJ, Knepper MA, DiGiovanni SR: Evidence for dual signaling pathways for V2 vasopressin receptor in rat inner medullary collecting duct. Am J Physiol 1996;270:F623-633.

62 Yip KP: Coupling of vasopressin-induced intracellular Ca2+ mobilization and apical exocytosis in perfused rat kidney collecting duct. J Physiol 2002;538:891-899.

63 Balasubramanian L, Sham JS, Yip KP: Calcium signaling in vasopressin-induced aquaporin-2 trafficking. Pflugers Arch 2008;456:747-754.

64 Feinstein TN, Wehbi VL, Ardura JA, Wheeler DS, Ferrandon S, Gardella TJ, Vilardaga JP: Retromer terminates the generation of cAMP by internalized PTH receptors. Nat Chem Biol 2011;7:278-284.

65 Calebiro D, Nikolaev VO, Gagliani MC, de Filippis T, Dees C, Tacchetti C, Persani L, Lohse MJ: Persistent cAMP-signals triggered by internalized G-protein-coupled receptors. PLoS Biol 2009;7:e1000172.

66 Nantel F, Marullo S, Krief S, Strosberg AD, Bouvier M: Cell-specific down-regulation of the beta 3-adrenergic receptor. J Biol Chem 1994;269:13148-13155. 


\section{Cellular Physiology Cell Physiol Biochem 2018;48:847-862 \begin{tabular}{l|l} 
DOI: 10.1159/000491916 & $\begin{array}{l}\text { O 2018 The Author(s). Published by S. Karger AG, Basel } \\
\text { www.karger.com/cpb }\end{array}$ \\
\cline { 2 - 3 } & Published online: July 20, 2018
\end{tabular} \\ Milano et al.: $\mathrm{B}_{3}$ ar Desensitization in Renal Cells}

-67 Esbenshade TA, Han C, Theroux TL, Granneman JG, Minneman KP: Coexisting beta 1- and atypical beta-adrenergic receptors cause redundant increases in cyclic AMP in human neuroblastoma cells. Mol Pharmacol 1992;42:753-759.

68 Abrams P, Kelleher C, Staskin D, Rechberger T, Kay R, Martina R, Newgreen D, Paireddy A, van Maanen R, Ridder A: Combination treatment with mirabegron and solifenacin in patients with overactive bladder: efficacy and safety results from a randomised, double-blind, dose-ranging, phase 2 study (Symphony). Eur Urol 2015;67:577-588.

69 Warren K, Burden H, Abrams P: Mirabegron in overactive bladder patients: efficacy review and update on drug safety. Ther Adv Drug Saf 2016;7:204-216.

-70 Herschorn S, Barkin J, Castro-Diaz D, Frankel JM, Espuna-Pons M, Gousse AE, Stolzel M, Martin N, Gunther A, Van Kerrebroeck P: A phase III, randomized, double-blind, parallel-group, placebo-controlled, multicentre study to assess the efficacy and safety of the beta(3) adrenoceptor agonist, mirabegron, in patients with symptoms of overactive bladder. Urology 2013;82:313-320.

71 Nitti VW, Auerbach S, Martin N, Calhoun A, Lee M, Herschorn S: Results of a randomized phase III trial of mirabegron in patients with overactive bladder. J Urol 2013;189:1388-1395.

72 Yamaguchi O, Marui E, Kakizaki H, Homma Y, Igawa Y, Takeda M, Nishizawa O, Gotoh M, Yoshida M, Yokoyama O, Seki N, Ikeda Y, Ohkawa S: Phase III, randomised, double-blind, placebo-controlled study of the beta3-adrenoceptor agonist mirabegron, $50 \mathrm{mg}$ once daily, in Japanese patients with overactive bladder. BJU Int 2014;113:951-960.

73 Chapple CR, Cardozo L, Nitti VW, Siddiqui E, Michel MC: Mirabegron in overactive bladder: a review of efficacy, safety, and tolerability. Neurourol Urodyn 2014;33:17-30.

74 Bankir L, Bichet DG, Morgenthaler NG: Vasopressin: physiology, assessment and osmosensation. J Intern Med 2017;282:284-297.

75 Firsov D, Bonny 0: Circadian regulation of renal function. Kidney Int 2010;78:640-645 